\title{
Effect of urea supplementation on urea kinetics and splanchnic flux of amino acids in dairy cows*
}

\author{
H. Lapierre ${ }^{1,4}$, D.R. Ouellet ${ }^{1}$, R. Berthiaume ${ }^{1}$, C. Girard ${ }^{1}$, \\ P. Dubreuil ${ }^{2}$, M. Babkine ${ }^{2}$ and G.E. Lobley ${ }^{3}$ \\ ${ }^{1}$ Agriculture and Agri-Food Canada, Lennoxville, Quebec, Canada \\ ${ }^{2}$ Université de Montréal, St-Hyacinthe, Québec, Canada \\ ${ }^{3}$ Rowett Research Institute, Aberdeen, Scotland, UK
}

\begin{abstract}
Five lactating dairy cows were used in a cross-over design to determine if increased hepatic ureagenesis affected hepatic removal of amino acids (AA). Hepatic ureagenesis accounted for all urea entry rate (measured with a 3 -d infusion of ${ }^{15} \mathrm{~N}^{15} \mathrm{~N}$-urea) and both increased with urea supplementation. Neither liver removal of essential AA or milk protein yield was affected by urea supplementation. Gut entry rate and its partition between anabolic and catabolic fates were also unaltered by treatment. Saliva contributed to 0.31 to 0.50 of urea gut entry rate. In cows producing $32 \mathrm{~kg} / \mathrm{d}$ of milk and fed a diet supplying $157 \mathrm{~g} \mathrm{CP} / \mathrm{kg} \mathrm{DM}$, increased hepatic ureagenesis did not result in decreased post-liver supply of essential AA and subsequent milk protein yield.
\end{abstract}

KEY WORDS: urea, amino acids, liver, gut

\section{INTRODUCTION}

Hepatic ureagenesis is a major crossroad of $\mathrm{N}$ exchange in dairy cows, equivalent to 0.80 of digested $\mathrm{N}$ (Lapierre et al., 2004). Hepatic detoxification of absorbed ammonia could involve increased catabolism of amino acids (AA) to provide, via aspartate, the other $\mathrm{N}$ atom required for urea synthesis (Parker et al., 1995). Nonetheless, when ammonia was infused into the mesenteric vein, increased hepatic removal of AA was not observed (Milano et al., 2000). Such infusions, however, do not simulate situations where excess of degradable protein is fed. Therefore, the objective of this study was to determine the effect of an excess supply of ammonia to dairy cows, induced by feeding urea, on urea kinetics and AA removal by the liver.

\footnotetext{
* Supported by La Fédération des Producteurs de Lait du Québec

${ }^{4}$ Corresponding author: e-mail: lapierreh@agr.gc.ca
} 


\section{MATERIAL AND METHODS}

Six multi-catheterized cows (artery, mesenteric, portal and hepatic veins) were used in a crossover design (28-d experimental period) to study the effect of dietary urea supplementation on urea kinetics and splanchnic metabolism of AA. One cow suffered acute mastitis during the first period and was removed from the study. Cows were fed, as 12 equal meals per day, a diet (DM basis: 0.19 grass hay; 0.25 maize silage; 0.36 maize grain; 0.11 soyabean meal; 0.05 whole soyabean; 0.04 mineral and vitamin premix; CP: $157 \mathrm{~g} / \mathrm{kg}$; MP: $1925 \mathrm{~g} / \mathrm{d}$ ) with or without urea added (15g/kg DMI). From d 24 to 28, total collections of urine and faeces were performed with, from d 25 to 28 , a concomitant infusion into a jugular vein, of ${ }^{15} \mathrm{~N}^{15} \mathrm{~N}$-urea $(0.30 \mathrm{mmol}$ urea-N/h). Samples of urine and faeces were taken on d 28 to determine the isotopic enrichment of ${ }^{15} \mathrm{~N}^{15} \mathrm{~N}$ and ${ }^{15} \mathrm{~N}^{14} \mathrm{~N}$ urea (urine) and total ${ }^{15} \mathrm{~N}$ (faeces). On one day during this period, six hourly blood samples were collected from the artery, portal and hepatic veins, with p-aminohippurate infused into one mesenteric vein (blood flow). Plasma urea and AA concentrations were measured as described in Raggio et al. (2004).

Urea kinetics was calculated as described previously (Lobley et al., 2000). Urea entry rate (UER) is eliminated in urinary urea excretion (UUE) or transferred to the gut (gut entry rate - GER). The latter is hydrolysed in the lumen by bacteria and the $\mathrm{NH}_{3}$ released can undergo three fates: excreted in faeces (UFE); re-entry the ornithine cycle (ROC); or use for anabolic purposes (UA - support of microbial protein synthesis). Net fluxes of urea and AA across the splanchnic tissues were calculated as the product of veno-arterial differences times blood water flow (urea) or plasma flow (AA). Data were analysed using the GLM procedure of SAS (SAS Institute, 2000), with treatment, cow and period as the main effects.

\section{RESULTS AND DISCUSSION}

Urea supplementation did not affect milk and protein yields which averaged 31.9 vs $32.4 \pm 0.74$ and 1.02 vs $1.07 \pm 0.023 \mathrm{~kg} / \mathrm{d}$, respectively ( $\mathrm{LSM} \pm \mathrm{SEM}$ for control vs urea will be given). Dry matter intake was also unaltered by treatment $(17.8 \mathrm{~kg} / \mathrm{d})$. Urea production, measured as hepatic ureagenesis (Table 2) or as UER (Table 1), increased with urea supplementation, on average by the same amount as the urea fed $(370 \mathrm{mmol} / \mathrm{h})$. Hepatic ureagenesis accounted for all the UER, indicating little ureagenesis from the kidneys. Urea supplementation increased $(\mathrm{P}<0.01)$ urinary urea excretion, both in absolute amounts (Table 1) and as a proportion of UER ( 0.25 vs $0.39 \pm 0.014)$. Although the proportion of UER returning to the gut decreased, the absolute amounts of urea transferred to the gut were not affected by urea supplementation (Table 1), despite an increased plasma urea-N concentration ( 7.6 vs $14.6 \pm 0.80 \mathrm{mM}$; $\mathrm{P}<0.01)$. The contribution 
Table 1. Effect of dietary urea supplementation on urea-N kinetics

\begin{tabular}{|c|c|c|c|c|}
\hline \multirow{2}{*}{ Urea kinetic variables, $\mathrm{mmol} / \mathrm{h}$} & \multicolumn{2}{|c|}{ Treatment } & \multirow{2}{*}{ SEM } & \multirow{2}{*}{$\mathrm{P}$} \\
\hline & control & urea & & \\
\hline Production (UER) & 691 & 1001 & 42.6 & 0.02 \\
\hline Entry to gut (GER) & 520 & 613 & 39.5 & 0.20 \\
\hline Urinary excretion (UUE) & 171 & 388 & 16.6 & $<0.01$ \\
\hline Return to ornithine cycle (ROC) & 203 & 237 & 18.2 & 0.27 \\
\hline Losses to faeces (UFE) & 47 & 31 & 2.5 & 0.03 \\
\hline Re-use for anabolism (UA) & 270 & 344 & 21.7 & 0.10 \\
\hline
\end{tabular}

Table 2. Effect of dietary urea supplementation on arterial concentration $(\mu \mathrm{M})$ of amino acids and net fluxes $(\mathrm{mmol} / \mathrm{h})$ of urea and amino acids

\begin{tabular}{|c|c|c|c|c|c|}
\hline \multirow{2}{*}{$\mathrm{AA}$} & \multirow{2}{*}{ Tissue $^{1}$} & \multicolumn{2}{|c|}{ Treatment } & \multirow{2}{*}{ SEM } & \multirow{2}{*}{$\mathrm{P}$} \\
\hline & & control & urea & & \\
\hline \multirow[t]{3}{*}{ Urea-N } & PDV & -341 & -300 & 48.7 & 0.59 \\
\hline & Liver & 667 & 1099 & 54.0 & 0.01 \\
\hline & TSP & 332 & 798 & 86.0 & 0.03 \\
\hline \multirow[t]{4}{*}{ Leu } & Arterial & 142.6 & 115.7 & 2.60 & $<0.01$ \\
\hline & PDV & 43.6 & 43.8 & 2.89 & 0.97 \\
\hline & Liver & 7.4 & 4.6 & 1.65 & 0.32 \\
\hline & TSP & 51.0 & 48.4 & 3.22 & 0.61 \\
\hline \multirow[t]{4}{*}{ Lys } & Arterial & 77.6 & 70.3 & 0.92 & 0.01 \\
\hline & PDV & 30.6 & 30.5 & 2.11 & 0.95 \\
\hline & Liver & 3.0 & -1.5 & 3.62 & 0.45 \\
\hline & TSP & 33.6 & 30.0 & 4.53 & 0.52 \\
\hline \multirow[t]{4}{*}{ Met } & Arterial & 13.8 & 13.4 & 0.24 & 0.32 \\
\hline & PDV & 9.1 & 8.6 & 0.49 & 0.56 \\
\hline & Liver & -1.9 & -1.6 & 0.39 & 0.64 \\
\hline & TSP & 7.2 & 7.0 & 0.66 & 0.86 \\
\hline \multirow[t]{4}{*}{ Phe } & Arterial & 47.0 & 37.3 & 1.57 & 0.03 \\
\hline & PDV & 22.6 & 21.9 & 1.13 & 0.72 \\
\hline & Liver & -8.0 & -7.6 & 0.63 & 0.68 \\
\hline & TSP & 14.5 & 14.3 & 1.14 & 0.91 \\
\hline
\end{tabular}

${ }^{1}$ PDV - portal drained-viscera; TSP - total splanchnic tissues

of saliva-urea to GER, estimated as GER minus urea portal flux, averaged 178 vs $313 \pm 66.5$. Although the diet effect was not significant (high SEM with the difference approach), the saliva contributed 0.31 vs $0.50 \pm 0.102$ of GER for the two diets. Once the urea was returned into the gut, its partition between catabolic losses (ROC plus UFE) and anabolic usage was not affected by treatment. 
For those AA mainly catabolised by the liver, e.g., Met and Phe, increased hepatic ureagenesis did not increase their hepatic removal (Table 2). As previously observed in dairy cows, there were little, if any, removals of the branched-chain AA and Lys across the liver, with these also not affected by treatment. As a result, net splanchnic release of essential AA was unaltered by treatment, in agreement with no responses in milk production. There was, however, a general decrease in circulating concentrations of essential AA $(\mathrm{P}<0.05)$ with the dietary urea supplement, except for Met.

\section{CONCLUSIONS}

In cows fed to protein requirements, hepatic removal of AA is already in excess of requirement for obligate functions (Raggio et al., 2004) and does not appear to respond to increased hepatic ureagenesis. If hepatic removal of ammonia for urea synthesis were to impact on increased hepatic removal of AA, with a subsequent detrimental effect on milk protein yield, this would be more likely at low protein supplies, but this hypothesis remains to be tested.

\section{REFERENCES}

Lapierre H., Raggio G., Berthiaume R., Thivierge M.C., Pacheco D., Dubreuil P., Lobley G.E., 2004. The route of absorbed nitrogen into milk protein. Anim. Sci. (submitted)

Lobley G.E., Bremner D.M., Zuur G., 2000. Effects of diet quality on urea fates in sheep as assessed by refined, non-invasive $\left[{ }^{15} \mathrm{~N}^{15} \mathrm{~N}\right]$ urea kinetics. Brit. J. Nutr. $84,459-468$

Milano G.D., Hotston-Moore A., Lobley G.E., 2000. Influence of hepatic ammonia removal on ureagenesis, amino acid utilization and energy metabolism in the ovine liver. Brit. J. Nutr. 83, 307-315

Parker D.S., Lomax M.A., Seal C.J., Wilton J.C., 1995. Metabolic implications of ammonia production in the ruminant. Proc. Nutr. Soc. 54, 549-563

Raggio G., Pacheco D., Berthiaume R., Lobley G.E., Pellerin D., Allard G., Dubreuil P., Lapierre H., 2004. Effect of metabolizable protein on splanchnic flux of amino acids in lactating dairy cows. J. Dairy Sci. (accepted) 